

DEN NORSKE LEGEFORENING

\title{
En bred juridisk gjennomgang
}

ANMELDELSER

\section{J.RGEN DAHLBERG}

Advokat, lege i spesialisering anestesi, klinisk stipendiat

Klinikk for kirurgiske fag,

Akershus universitetssykehus

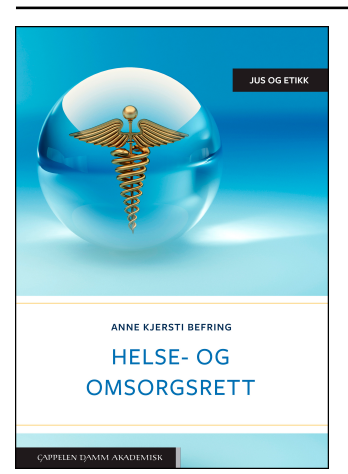

Anne Kjersti C. Befring

Helse- og omsorgsrett

Jus og etikk. 261 s, ill. Oslo: Cappelen Damm Akademisk, 2017. Pris NOK 398

ISBN 978-82-02-42501-2

Helse- og omsorgsrett er først og fremst skrevet som lærebok for helsefagstudenter, men er ment å kunne leses av alle som jobber innen helse- og omsorgsfag. Den dekker et vidt spekter av aktuelle temaer, som trolig med rette kan sies å omfatte de viktigste temaene innen helse- og omsorgsretten.

Gjennomgangen fremstår pedagogisk med innledende generelle kapitler etterfulgt av mer spesifikke temaer, som så avsluttes med noen avgrensede kapitler rundt ulike temaer om forvaltning, klage, straff osv. Både somatikk og psykiatri, primær- og spesialisthelsetjeneste er omtalt, og et flertall av de klassiske juridiske temaene som selvbestemmelse, tvang, forsvarlighet og taushetsplikt er godt behandlet.

Boken bærer preg av å være skrevet av en jurist med inngående kunnskap innen fagfeltet. Juridiske temaer og problemstillinger beskrives på en god måte innenfor bokens tiltenkte ramme. Den juridiske tilnærmingen kan av noen oppfattes noe fremmed fra det helsefaglige. For en helsefagstudent uten noen annen juridisk bakgrunnskunnskap vil noen deler således kanskje oppfattes som vanskelig tilgjengelig.

En gjennomgang av så mange, store og vanskelige temaer må nødvendigvis bli noe generelle. Særlig de innledende kapitlene bærer noe preg av dette. Bokens styrke, å dekke et 
vidt antall temaer på en kortfattet måte, medfører dermed også noen begrensninger. Eksempelvis vil de som søker en inngående gjennomgang av etikkens forankring på dette området trolig oppleve at boken er noe kortfattet.

Utgivelsen vil trolig egne seg godt for de fleste som ønsker en innføring eller kortfattet generell oppslagsbok i de vanligste juridiske temaene på dette fagfeltet. Den er således også en velegnet lærebok for de som tar hensyn til at boken er en juridisk fagbok.

Publisert: 11. februar 2019. Tidsskr Nor Legeforen. DOI: 10.4045/tidsskr.18.og10

(C) Tidsskrift for Den norske legeforening 2020. Lastet ned fra tidsskriftet.no 